\title{
THE RHIZOMATIC LEARNING FROM A PERSPECTIVE OF POSTSTRUCTURALISM
}

\author{
AIDA KAIRIENE் \\ Vytautas Magnus university, Academy of Education \\ Jonavos St.66, Kaunas, Lithuania \\ Email address: aida929@gmail.com \\ ORCID: https://orcid.org/0000-0002-4520-8732
}

\begin{abstract}
Aim. The branch of postmodernism is poststructuralism - in fact, it was called French poststructuralism, with the dominant philosophy being "68 philosophy" (Marshall, 2004). Nowadays students can learn English not only in formal but also in non-formal and informal forms. This enables the development of rhizomatic learning, the origins of which lie in Gilles Deleuze and Felix Guattari (2004) philosophy. Thus, the problem related question arises: what is the essence of rhizomatic learning from a perspective of poststructuralism? The aim of the study is to review theoretical considerations in order to reveal the essence of rhizomatic learning from a perspective of poststructuralism.

Method. The research method - a scientific literature review. The literature review examines relevant, current, and recent literature (Grant, \& Booth, 2009). The literature review period contains philosophical and educational literature from 1968 till now.

Results. The rhizomatic learning based on Gilles Deleuze's and Felix Guattari's (2004) term of rhizome, which has neither beginning nor end (Cormier, 2008), providing a dynamic, open, personalized learning network created by learners themselves that meets their perceived and real needs (Lian, \& Pineda, 2014).

Conclusion. The scientific analysis revealed that rhizomatic learning develops through Deleuze, Guattari concepts, especially through becoming learner and occurs in lifelong learning of English.
\end{abstract}

Key words: rhizomatic learning, Deleuze, Guattari, becoming, nomad.

\section{INTRODUCTION}

Dostmodernism emerged in the second half of the twentieth century, when 1 the terms "postmodernism", "postmodernity", "postmodernist" used to spread to various cultures and humanities, and their inflation and uncertainty began to appear. The situation of contemporary postmodernism in education can be defined as uncertainty, world recognition and confinement (Rubavičius, 2010), transformations of becomings (Mažeikis, 2013), seeking the meaning and perspectives of learning. Language learning is one of the key aspects of the 
modern postmodern situation. The Lifelong Learning strategy enhances the functioning of multilingual competence. At the heart of this competence is the ability to use various languages properly and effectively in communication. It is based on the ability to understand, express and interpret concepts, thoughts, feelings, facts and opinions. The Council of Europe Recommendations (2018) on Key Competences for Lifelong Learning consolidates the functioning of multilingual competence. At the heart of this competence is the ability to use various languages properly and effectively in communication. It is based on the ability to understand, express and interpret concepts, thoughts, feelings, facts and opinions, both verbally and in writing (listening, speaking, reading and writing) on an appropriate scale of societal and cultural contexts according to each person's wishes or needs. These skills (reading, listening, writing and speaking) are also embodied in Secondary school languages curriculum (2013). The Good School Concept (2015) emphasizes the future transition from education for all to education for everyone, personalized education and training, recognising that people's experiences, needs, aspirations are different and learning at different rates and ways. Students at "cosmic speed" must adapt to newly created programmes, be fluent in one or two foreign languages, be creative, innovative and critically minded. According to the Eurydice (2017) study, 9 out of 10 students in the European Union study English. Students can learn English not only in formal but also in non-formal and informal ways. This enables the development of rhizomatic learning, originating from the philosophy of Gilles Deleuze and Felix Guattari (2004). Thus, the following problem-related question arises: what is the essence of rhizomatic learning from the poststructuralist perspective?

The aim of the study is to review theoretical considerations to reveal the essence of rhizomatic learning of English from the perspective of poststructuralism.

The research method - a scientific literature review. The review examines relevant, current, and recent literature (Grant, \& Booth, 2009). In consideration of the research problem, the research methodology is based on philosophical and educational insights. The following sources have been selected for the analysis of rhizomatic learning of English: 1) philosophical and educational books that help to reveal the essence of rhizomatic learning; 2) publications and dissertations on the issue of rhizomatic learning, which helped to analyse the essence of rhizomatic learning from the perspective of poststructuralism. The literature review period contains from 1968 year till now. Firstly, the following literature of poststructuralism was analysed, such as Jacques Derrida On Grammatology (1968), Michael Foulcalt The Madness and Civilization (1967), Julia Kristeva Semiotics (1969), but the most influential work was Gilles Deleuze and Felix Guattari A Thousand Plateaus: Capitalism and Schizophrenia (2004). The ideas of Deleuze and Guattari (2004) were applied to education in Ina Semetsky Learning with Bodymind (2013), Lilija Duoblienè Learning as Swimming: Imaginational School Project in Deleuzean Way (2014), Jūratè Baranova Deleuze and Education (2017) and in other works. It should be mentioned that antecedences 
of rhizomatic learning were revealed in Gilles Deleuze, Felix Guattari (2004) philosophy. The later rhizomatic learning concept and its consequences were analysed. The various works were analysed, such David Cormier Rhizomatic Education: Community as Curriculum Innovate(2008), Andrew Lian, Maria Victoria Pineda Rhizomatic Learning: "As... When ... and If..." (2014) and other works. The detailed literature analysis helped to disclose the essence of rhizomatic learning from the perspective of poststructuralism.

\section{THE IDEAS OF GILLES DELEUZE AND FELIX GUATTARI IN EDUCATION}

One of the most significant philosophical streams of the second half of the twentieth century is post-structuralism that emerged in France in the 1960s and 1970s, i.e., the period of political unrest, rebellion, disillusionment with traditional values, accompanied by a resurgence of feminism, nihilism. It is like a new freedom, an action (Peters, \& Burbules, 2004), a movement for resistance to generalization, it is like a challenge to the established structures and hierarchies (Usher, \& Edwards, 1994) it is a change of structuralism. The dominant philosophy is "1968 philosophy" (Marshall, 2004). In that period, alongside the influential works, such as Jacques Derrida On Grammatology (1968), Michael Foulcalt The Madness and Civilization (1967), Julia Kristeva Semiotics (1969), emerged the personalities Gilles Deleuze and Felix Guattari. It should be noted that Gilles Deleuze was an original philosopher studying various sources of famous philosophers such as Benedict Spinoza, Gottfried Wilhelm Leibniz, David Hume, Emanuel Kant, Henri Bergson, Friedrich Nietzsche, Sigmund Freud and Karl Marx. His work, Nietzsche and Philosophy (1962), became the author's source of inspiration for nomadic thinking. Gilles Deleuze (1962) studied considered Friedrich Nietzsche. The Will to power is endless, as is the nomadic journey, one that fosters a nomadic life that transcends established order and boundaries, seeking another force to compete with and compete with. Thus, nomadic thinking is analogous to rhizomatic thinking, where there is no established hierarchy and structure. Poststructuralist thinking makes a significant contribution to learning by encouraging a constant rethink of the current state. In the poststructuralist era, distrust of metanarratives emerged, irrespective of its unifying tendencies, i.e., whether it is speculative or liberation narrative, this mistrust evolved as science evolves. It is important to restore the unity of scientific disciplinary knowledge, which can only be done through linguistic game by linking them as appropriate stages of becoming (Lyotard, 1993). Thus, Jacques Derrida (1968) developed a new way of philosophical analysis - deconstruction. Meanwhile, Julia Kristeva (1969) became famous as an interpreter of Michael Bakchtin's theories. Michel Foucault (1967) explored the relationship between madness and common sense. Poststructuralism calls for rethinking, it enables to doubt how we are thinking. The concept of post-structuralism offers the opportunity to create new spaces of learning that have 
been closed, hidden, or skewed in some way, not newly created. In this view, teaching is like an art, and the effective learning is achieved when each person creates a network of his or her own power and knowledge.

While analysing Gilles Deleuze's ideas on language learning, his work Difference and Repetition (1968) should be mentioned, where the author compares foreign language learning with the swimming process: "Learning to swim or learning a foreign language, all these compose each one's own body or one's own language" (Deleuze, 1994, p. 192). So, to learn a foreign language well, there is always a repetition that is different in each case. Each student is an individual and it is clear that learning will be different. In addition, the teacher is like an authoritative personality, whom the students are drawn to. Ina Semetsky (2013) believes that the idea of swimming comes from Gottfried Wilhelm Leibniz. A novice athlete learns to swim, willingly, and finds himself in the water during intense body waves. Learning occurs when the body practically actualizes many possibilities. Learning cannot be based on a prior imaging (Semetsky, 2013). The author relates it to sports and associates the aforementioned swimming with bodybuilding activities. Next, Lilija Duoblienè (2014) compares Deleuze's insights to the ones of Salomon Maimon, who considers water as divine wisdom, and swimming in the sea means being in a space where riches like pearls are somewhere very deep. They reflect wonderful ideas and knowledge that can only be acquired when someone is ready for them. According to Gilles Deleuze (1994), learning always takes place in and through the subconscious mind, thus, engaging with nature and mind. Moving into the educational process, pearls are accessible not to everyone only to the most gifted. Thus, we can understand the importance of learning that Deleuze brings, when a teacher becomes a facilitator, a coordinator, not just a knowledge provider. Cristian Beighton (2015) claims that Gilles Deleuze develops the idea of lifelong learning, it emerges when there is creativity, but according to Gilles Deleuze, this is only true if to create is understood as, first of all, to engender "thinking" in thought.

Another equally important personality was the psychotherapist and anarchist Fellix Guattari. The concept of schizoanalysis - the analysis of lines, spaces and becomings. Audronè Žukauskaitè (2004) distinguishes between contradictions and argues that psychoanalysis seeks to rebuild a patient's imaginary or symbolic identity into a lost meaning field. However, schizoanalysis does the opposite: it explores phenomena to restore lost meaning by asking how they function and what effects they produce. The concept of schizo - quickly spread into the field education. According to Lilija Duobliene (2017), today's global and, accordingly, national education policy requires a standardized image of a good teacher, on the other hand, it creates a need for innovativeness and creativity, which are essentially the opposite of standardization. This creates a schizoidic situation where contradictions paralyze the teacher's activity and motivation to act. As a solution, the author proposes a micropolitical change this situation where the teacher could change the situation with innovative thinking, creativity and tactics, focus on habits, 
creating the situation that is not about resistance but about new nomadic journeys in the learning process.

Interestingly, Franco Berardi (2008) describes Deleuze without Guattari and Guattari without Deleuze. The idea Deleuze without of Guattari spread throughout the history of Western philosophy, and the author not only wanted to free the concept of the event from any metaphysical reduction, but also analysed Friedrich Nietzsche's philosophical insights, and expanded the rhizomatic field. Meanwhile, Guattari without Deleuze constructed a philosophical style, drawing on the practice of psychiatry, starting with his work as a political fighter and finishing his studies in biology and pharmacology. These gave rise to composition of molecular "disassembly", assembly, and fission. Felix Guattari brought a specific micromaterial to his research into the rhizomatic field. The thinking created by Gilles Deleuze is not a maze, as the maze goes, and you can go anywhere. Furthermore, the maze is not related to another plane. Consequently, we cannot escape. No lines of flight here. So, in this case, it is not labyrinthine, but rather rhizomatic thinking. Felix Guattari wrote more about global capitalism, but he was always interested in machines, treating the subconscious as a functioning desire machine, and arguing that if we leave a part of the machine to our fate, we will not understand how the whole machine functions. Following the Gilles Deleuze and Felix Guattari's (2004) theory and its repercussions in poststructuralist philosophy, the paper seeks to reveal the authors' ideas in teaching a foreign language (English) at school to define the concept of rhizomatic learning from a poststructuralist perspective.

\section{THE ANTECEDENTS OF RHIZOMATIC LEARNING - RHIZOME AND OTHER CONCEPTS OF GILLES DELEUZE AND FELIX GUATTARI}

Rhizome. Gilles Deleuze (2014) together with psychoanalyst, psychotherapist and anarchist Felix Guattari, who is interested in schizoanalysis, wrote a two-volume work, entitled Capitalism and Schizophrenia. The first volume is Anti-Oedipus (1972), written in France long ago, is like a new vision and thinking style. Meanwhile, the other part The Thousand Plateaus (1980) is a new book of concepts. In this volume, the authors seek to reduce being to events by identifying it with becoming that is always molecular, encompassing going and moving. Here, a new concept of rhizome is introduced, which leads a completely different image - multiple assemblage, where there is no hierarchy, no authorization, no pressure. As things change over time, the school community increasingly needs new vision, new light, new concepts. Today, we are not inspired by computers, but by microbiology of the brain: the brain resembles to rhizome (Deleuze, 2012, p. 233). Rhizome is a derivative, without a common centre consisting of micro and macro multiplicity. Rhizome has neither a beginning nor an end, it consists of "lines of flight" and assemblages. Rhizome is always associated with a map being created, constructed, with multiple 
inputs and outputs and lines of flight. Gintautas Mažeikis (2013) notes that Gilles Deleuze and Felix Guattari (2014) derive rhizome from non-linear and non-linear dialectics of Theodor Adorno. Such a rhizomatic way of learning creates plateaus that bring new changes into education system. New curriculum is being formed on the rhizome plane, where innovation and perspectives are created by lines of flight. Furthermore, rhizome can be seen as a polymorphic vision of the postmodern world, a flexible postmodern thinking, a metaphor, which does not have a clear structure, for strict causality, centralization, order, and symmetry, and the key features of the rhizome are the astronomical processuality, the unprogrammed that unfolds in the spontaneous flow of the creative spirit, like the flow of consciousness. It is a contradictory view of a postmodern world without centralization, the asymmetry of disciplinary order (Andrijauskas, 2010). On the other hand, from a centralized standpoint, disciplinary order can be liberated by revolutionary desire (Pocius, 2011), which involves student-teacher relationships. According to Lilija Duobliene (2017), a teacher is one of the participants in a connected network, just like a learner, so he is depended on the environment and uses it not only for himself, but also for activating students if they do not have the potential for action. This effectively creates a positive relationship between community members that leads to further focused action. The rhizome does not have points or positions as those found in the structure, tree or root. There are only lines. The lines belong to a continuous space consisting of many nomadic multiplicities. It is the idea of rhizome multiplicity that helps to understand how assemblage works (Žukauskaite, 2011). Thus, we can assume that in the education system, English language learning is rhizomatic, forming language learning assemblages.

The assemblages of language. According to Gilles Deleuze and Felix Guattari (2004), the rhizome is composed of micro and macro multiplicities, and their overlapping or merging is called assemblage. A school can have molar and molecular assemblages. When English is taught in a strictly defined structure, a molar assemblage is formed, and when the curriculum develops in various forms, a molecular assemblage is formed. According to Audrone Žukauskaite (2011), the assemblage is always associated with a certain territory. While being territorial, it belongs to a certain stratum, i.e., the stratum, and the only identity of the assemblage is functioning, for which symbiosis is important, i.e., sympathy. The strict English language learning system of the molar assemblage is based on territorialisation: this closed area is dominated by a teacher to student relationship, and the molar assemblage appears, when there is a teacher-student mutual relationship: it lies in deterritorialization of English language learning. Deterritorialization is like a new territory with "lines of flight" and assemblages, where all lines are like bridges to a new direction. "Lines of flight" are movements of deterritorialization. In the process of learning, these are some English language areas, not discovered by the learner yet, meaningful achievements and other.

War machines. Gilles Deleuze and Felix Guattari (2004) introduces the concept of "war machine", which is an assemblage that creates various forms of 
becoming and producing qualitative change. According to the authors, it is one of the desire machines. The machines of desire are placed inside of one another and connecting each other from outside, thus, there are many of them. The desire machine is a machine that is generated and set up as an assemblage. The desire assemblages create two kinds of machines, i.e., state apparatus machine, which operates on the organizing plane, and the war machine, operating on the immanent plane of assemblages (Žukauskaitè, 2011). Consequently, the entire education system is based on the principles of machine operation, but the rhizomatic learning of English is possible, when the revolutionary desire machine, initiating the operation of the war machine, is subconsciously exposed. Thus, the war machine is used by every teacher and student who opposes the "state apparatus" for innovation. By way of example, the machines in the literature at Kafka's Criminal Colony include Raymond Roussel's machines, certain Edgar Allan Poe's machines, etc. The qualitative changes occur in the smooth and immanent plane.

The smooth (immanent, continuous, nomadic) plane of English learning. The striated plane (striated space). A smooth (immanent, continuous, nomadic space) plane is the plane where change takes place and can be conquered. It is a horizon-free environment that is a smooth space, steppe, desert, or sea. A smooth space is an immanence plane with a greater power for new developments and perspectives in language learning. Deterritorialization is a new territory with "lines of flight," spatial and temporal inequalities, where all lines are like bridges towards a new direction. Another space, opposite to continuous space, is a divided space. It is important to note that in a smooth space of a good school, there are transformations, advantages, directions of deterrence, various transformations, vigorous English-language machine learning innovations, but in the opposite direction of another "fascist machine" in a divided space that seeks to reverse these qualitative changes and enable the order. In a split plane, lines or trajectories are usually subordinated to points, one going from one point to another. According to Gilles Deleuze and Felix Guattari (2004), in contrast to the sea, the city is a divided plane par excellence; the sea is a continuous space, but the sea can flood the city, creating a continuous space. Divided space is constant. The smooth space is always characterized by a greater power for deterritorialization - new developments and perspectives in language learning. Deterritorialization is a new territory with "lines of flight", spatial and temporal inequalities, where all lines are bridges to a new direction. "It would seem that a whole nomad science develops eccentrically, one that is very different from the royal or imperial sciences. Furthermore, this nomad science is continually "barred," inhibited, or banned by the demands and conditions of State science" (Deleuze, \& Guattari, 2004, p. 362). David Cole (2014) believes that educational nomadology will be legitimized by future generations who will work to remove stress from the education system; they will build new non-sedentary schools, the curriculum will include self-contained teaching and learning units that address local issues and integrate universal knowledge 
into sustainable school life. For the school community, these are new challenges that will bring new change. At school, this manifests itself as the power of the students against the set rules. For English learners, it is important that a lesson recognizes his or her ability to achieve in an informal way. When informal learning invades the formal learning space, it creates a smooth space, changes take place; however Gilles Deleuze and Felix Guattari (2004) believes that one must never believe that a smooth space is enough to save us. In a smooth space, points are subordinated to the trajectory. It is like a nomadic dwelling, subordinated to a trip. Students learn languages with a purpose in mind, for example, some students seek to pass their exams and enter higher education in Lithuania or abroad, while others plan to travel or take a gap year, thus, being is on his or her journey to success.

Becoming a learner. According to Gilles Deleuze and Felix Guattari (2004), becoming is the transition from quantitative to qualitative plurality. "Becoming - is not matching or similarity, imitation or identification. Becoming does not occur in the imagination, even when the imagination reaches the highest cosmic or dynamic level, as in Jung or Bachelard's work" (Deleuze, \& Guattari, 2004, p. 238). Thus, becoming is considered as a process of change, flight, or movement inside the assemblage. Audronè Žukauskaitè (2011) analyses the concept of becoming more broadly and gives the following definition: "Being is a specific state of movement and calmness, speed and slowness, intensity point flows" (Žukauskaitè, 2011, p. 117). At school, becoming is created at the micro level, where, according to Gintautas Mažeikis (2013), change at the molecular or micro level is particularly important as it is related to the individual's search for "unfinished assemblage duality" and "heterogeneous swarms of multiplicity" (Mažeikis, 2013, p. 215). This is equated with the endless development of good examples of learning that is continually ongoing, boundless and unpredictable. Becomings are always molecular. Becoming is not an imitation, or an identification with something, it is becoming. In addition, becoming is always a minority, there is no becoming a majority, becoming is always in a middle - intermezzo (Deleuze, \& Guattari, 2004). In a learning situation, it can be becoming a learner, becoming a nomad. These types of learning embed the lifelong learning. Christian Beighton (2015) observes the creation of spaces for lifelong learning, which are like changing territories where conceptualization processes take place, implying the changes in practice for all participants. However, according to Gintautas Mažeikis (2013), there may be other transformations of the learner; entanglement of others, dislocation. It is like a desire to learn. Confrontation - return to the path of true being, divine rebirth, resurrection - to the rebirth of the soul. This is the desire to exit the entanglement state, e.g., after completing a hard compulsory English task. All these metamorphoses are particularly prominent in literature, where metamorphoses give a work a literary charm and a creative portrayal. The opposite force is demonstrated by anamorphosis of English language learning, which is like an anti-interference, when learning becomes absurd and meaningless. 


\section{FROM RHIZOME TO RHIZOMATIC LEARNING: THE CONCEPT OF RHIZOMATIC LEARNING}

Jenny Mackness, Frances Bell, \& Mariana Funes (2016) surveyed the respondents, involved in rhizomatic learning, in order to understand what is rhizomatic learning in their view. According to the respondents, rhizomatic learning "involves network and community", "rhizomatic learning is related to communications, network", "rhizomatic learning is not traditional learning that focuses on communication". Consequently, it might be stated that rhizomatic learning is not a traditional learning, opposed to hierarchy, connected. In the linguistic context, rhizomatic learning is a relatively new concept. The word rhizomatic is derived from the botanical term rhizome (gr. rhizoma), meaning the stem of an underground plant that emits roots and shoots from its nodes. These are simply rhizomes. In philosophy, the term rhizome was developed by Gilles Deleuze and Felix Guattari (2004), who also identified it with the botanical term rhizome, which can be used to explain non-botanical areas such as politics, education, education, etc. Meanwhile, the term of learning is characterized by deeper traditions of consumption. "Learning is the ability to do what you couldn't do before then" (Cronje, 2018, p. 1). Obviously, learning involves much more than memorizing and remembering information. Deep and longterm learning includes understanding, linking ideas and connecting previous and new knowledge, independent and critical thinking, and the ability to transfer knowledge to new and different contexts. Rhizomatic learning in Lithuanian itself is a relatively new concept and only few researchers have been using it, however, it slowly penetrates into the medium of Lithuanian language. It should be noted that some researchers (Koutropoulos et al., 2016; Bozkurt et al., 2016; Cormier, 2008) associate the concept of rhizomatic learning with quantitative access. David Cormier (2008), who applied the theory of Gilles Deleuze and Felix Guattari (2004) is considered to be the creator of the concept of rhizomatic learning. Although the author is not very keen on defining the concept of rhizomatic learning, the review of his articles reveals that rhizomatic learning is viewed as a non-traditional learning, based on Gilles Deleuze's and Felix Guattari's (2014) rhizomatic term, which focuses on communication and where the curriculum develops a in real time. Apolos Koutropoulos et al. (2016), Aras Bozkurt et al. (2016), Jenny Mackness, Frances Bel, \& Mariana Funes (2015), Cormier (2008) tend to associate rhizomatic learning with distance learning, especially with MOOC (massive open online courses), where learners form a rhizomatic learning network. Bozkurt et al. (2016) believe that rhizomatic learning focuses on how learners seek knowledge and is based on creative learning through networking. Thus, rhizomatic learning occurs by connecting and developing relationships, while knowledge is created by the learners themselves. According to Mackness \& Bell (2015), rhizomatic learning is about shaping the learning community and creating curriculum in a real time. It should be noted that rhizomatic learning is becoming increasingly important (Cormier, 2008), especially in the field of distance learning (Mackness \& Bell, 2015). 
Talking about rhizomatic learning from qualitative perspective, it might be observed that rhizomatic learning develops through Gilles Deleuze and Felix Guattari (2014) concepts. Furthermore, the manifestations of rhizomatic learning can be found in the works of Rita Bissola (2017), Violet Adams Ellis (2016), Andrew Lian, Maria Victoria Pineda (2014), Kathy Sanford, Lizz Merkel, Leanna Madill (2011). According to Kathy Sanford, Lizz Merkel, Leanna Madill (2011), rhizomatic learning is a complex learning process to observe and recognise the "reality". The authors associate rhizomatic learning as learning through games that can be played online. Thus, English can be learned through a variety of games. Rhizomatic learning broadens learners' knowledge, encourages peer-to-peer collaboration, and can take place anywhere, using various learning tools. Hence, English language can be learned in many forms, creating a personal learning space. This is also confirmed by Andrew Lian and Maria Victoria Pineda (2014), who argue that rhizomatic learning is the learning that creates a dynamic, open, personal learning network, formed by the learners themselves, in line with their perceived and real needs. The authors support the idea that the aforementioned form is appropriate for language learning. Meanwhile, other researchers (Bissola, 2017; Bell, Mackness, \& Funes, 2016; Chan, 2010) associate rhizomatic learning with the development of curriculum. According to Kirsten Ho Chan (2010), rhizomatic learning is a continuous, dynamic learning process that takes into account students' desires and their experiences in creating the "flight paths" without any ends and beginnings. Rita Bissola (2017) emphasises that this is effective in the implementation of curricula and that the views, values and experiences of each community member should be considered when developing the curriculum. In summary, rhizomatic learning is the learning based on Gilles Deleuze's and Felix Guattari's (2004) term of rhizome, which has neither beginning nor end (Cormier, 2008), providing a dynamic, open, personal learning network that is constructed by learners themselves and their real needs (Lian, \& Pineda, 2014). The concept of rhizomatic learning has its own meaning, but is closely related to the concepts of Gilles Deleuze and Felix Guattari (2004), i.e., rhizome, assemblage, becoming, nomad, etc. It is learning that can take many forms. It should be noted that the rhizomatic learning from post-structuralism perspective develops and manifests itself through various moving concepts of Gilles Deleuze and Felix Guattari (2004).

\section{THE CONSEQUENCES OF RHIZOMATIC LEARNING}

Many of those in the field of education believe that new concepts are needed to think and live differently. According to Elizabeth St. Pierre (2004), the concepts of Gilles Deleuze and Felix Guattari (2004) should be used in education as have already been used by people in their experience, e.g., a body without organs. Body without organ is a smooth space undergoing qualitative change. While teaching students, the author noticed that they create exciting lines of 
flight, responding to the concepts of rhizomes, nomads, organs, etc. The educators are encouraged to look for continuous space, but Gilles Deleuze and Felix Guattari (2004) believe that continuous space cannot always save. In his book Deleuze, Education and Becoming, Ina Semetsky (2007) approaches Gilles Deleuze's texts in terms of contemporary philosophy of education. The author pays great attention on becoming (French devenir), created by Deleuze by taking over the Nietzsche's being as metaphysics of becoming. In describing various becomings, besides the ones of becoming a language, becoming a rhyme, becoming a sign, becoming a child, the author distinguishes between becoming a nomad. It is important to note that nomadicity manifests itself through experience, through movement, revealing its ethical, artistic and emotional qualities (Semetsky, 2007), and is the derivative of war machine and smooth space (Deleuze, 2012). This is also true in the educational space when learning languages: by learning languages, students at school become like nomads travelling in different directions. Education theorists associate rhizomatic learning with nomadic pedagogy. Nomadic pedagogy is referred to as a learning process in which learning is a change that occurs by engaging in things in an unknown area in order to make new discoveries. Interestingly, Jūratè Baranova (2017) argues that if Guattari had discussed the case of the nomadic disciple, he would have concluded that his desire would be to overthrow the social hierarchy and take the position of the one who judges and controls the situation. In this situation, besides being nomadic, we can talk about becoming a learner. Becoming a learner is marked by a desire to learn English, creating nomadic learning paths and revealing directions of learning. In this situation, learners are driven by the desire to learn English in many forms. They can be motivated by intrinsic and extrinsic motivations, but with the same goal of learning English. Thus, these practices construct and deconstruct relatively different configurations and, over time, reflect the nomadic experience of becoming a learner (Fedler, 2013). The educational dissertations (Johnston, 2018; Charney, 2017, Gabi, 2013; Waterhouse, 2011) reveal the manifestations of rhizomatic learning. Rhizomatic learning is used in teaching (Johston, 2018), professional development of language teachers, in the process of creating becomings (Charney, 2017; Waterhouse, 2011). According to Renee Charney (2017), rhizomatic learning is a kind of learning practice that has shattered the traditional, standardized institutional learning system and forced to think about how and when that learning should take place. However, rhizomatic language learning should also be based on the curriculum content, enabling teachers and students to create it, and on various forms of learning.

\section{DISCUSSION}

Analysis of the essence of rhizomatic learning revealed that rhizomatic learning is an appropriate way of learning English and is based on the concepts developed by Gilles Deleuze and Felix Guattari (2004). This idea is supported 
by research carried out by a number of scholars (Lian, Pineda, 2014; Masny, 2014). Diana Masny (2014) believes that Immigrant's Learning of English as a second foreign language causes transformation in person and creates new becoming. According to Andrew Lian and Maria Victoria Pineda (2014), the learners of languages in a rhizomatic way create a personal learning environment. Many authors (Mackness \& Bell, 2015; Bozkurt et al., 2016; Cormier, 2008) associate rhizomatic learning with distance learning. This is not exactly purposeful learning according to the curriculum, the initiators of learning are the students themselves and the role of a tutor is assigned to the teacher. Rhizomatic learning forms an open, dynamic, personalized learning network that is created by the learners themselves according to perceived and real needs (Lian \& Pineda, 2014). So, new becoming is created - becoming a learner (Fedler, 2013), where a learner, like a nomad, wanders into the grip of nomadic pedagogy. The potential for rhizomatic possibilities is beyond measure. There is a widespread use of rhizomatic learning in a distance learning of languages, using various online resources: social networks, blogs. On the other hand, rhizomatic learning can take the form of intensive libraries, books, and manuals. It should be noted that the very concept of rhizomatic learning is still new. Drawing on the ideas of Gilles Deleuze and Felix Guatari (2004), the concept of rhizomatic learning was used by Cormier (2008), arguing that rhizomatic learning is not a traditional learning: here the focus is on communication, and the idea of learning is that the curriculum is not predefined, it develops in a real time (Cormier, 2008). The rhizomatic learning of language is manifested through the concepts developed by Deleuze, Guattari (2004). Thus, it might be stated that rhizomatic-based learning is an essential core of language learning (Lian \& Pineda, 2014, Masny, 2014, Waterhouse, 2011), where it acquires new learning abilities, but as it has already been mentioned, the curriculum should also be taken into account.

\section{CONCLUSIONS}

This theoretical analysis revealed that rhizomatic learning, which originated from the Gilles Deleuze and Felix Guattari's (2004) term "rhizome," has evolved into a number of "moving" concepts as assemblage, becoming, nomad, etc. However, there are micro- and macro-learning assemblages at school, creating both contrasts and complementarities. The key to this situation is becoming a learner, leading to the emergence of nomadism, plotting the direction of lifelong learning. The task of the war machine is to produce qualitative changes by creating new learning becomings and assemblages. Rhizomatic learning is the kind of learning that manifests itself in various forms, for example in formal, non-formal and informal way. The essence of rhizomatic learning of English language is to embed the English language as best as possible through various forms of learning. 


\section{REFERENCES}

[1] Andrijauskas, A. (2010). Neklasikinès ir postmodernistinés filosofijos metamorfozés [Metamorphoses of non-classical and postmodern philosophy]. Vilnius: Meno rinkos agentūra.

[2] Baranova, J. (2017). Deleuze and education. European Journal of Social Sciences, 4(3), 151-161.

[3] Bell, F., Mackness, J., \& Funes, M. (2016). Participant association and emergent curriculum in a MOOC: Can the community be the curriculum? Research in Learning Technology, 24, 1-19.

[4] Beighton, C. (2015). Deleuze and lifelong learning: creativity, events and ethics. New York/ London: Palgrave Macmillan.

[5] Berardi, F. (2008). Felix Guattari: thought, friendship, and visionary cartography. New York/ London: Palgrave Macmillan.

[6] Bissola, R., Imperatori, B., \& Biffi, A. (2017). A rhizomatic learning process to create collective knowledge in entrepreneurship education. Open innovation and collaboration beyond boundaries. Management Learning, 48, 206-226.

[7] Bozkurt, A., Honeychurch, S., Caines, A., Bali, M., Koutropoulos, A., \& Cormier, D. (2016). Community tracking in a cMooc and nomadic learner behavior identification on a connectivist rhizomatic learning network. Turkish Online Journal of Distance Education, 17, 4-30.

[8] Charney, R. (2017). Rhizomatic learning and adapting: A case study exploring an interprofessional team's lived experiences. Ed. Dissertation. 1-203. Retrieved from January 15, 2020, from https:/ / aura.antioch.edu/cgi/ viewcontent.cgi?article=1392\&context=etds

[9] Cole, D. (2014). Inter-collapse... educational nomadology for a future generation. In M. Carlin, J. Wallin (Ed.), Deleuze and Guattari, politics and education (pp. 77-95). London: Bloomsbury.

[10] Cormier, D. (2008). Rhizomatic education: community as curriculum innovate. Journal of Online Education, 4(5), 1-8.

[11] Cronje, J. (2018). Towards a model for assessment in an information and technology-rich 21st century learning environment. Urbana, IL: university of Illinois and Indiana university, national institute for learning outcomes assessment (NILOA),1-1.

[12] Chan, K. H. (2010). Rethinking children's participation in curriculum making: a rhizomatic movement. In V. Pacini-Ketchabaw (Ed.), Flows, rhythms, and intensities of early childhood education curriculum (pp. 107-122). New York: Peter Lang.

[13] Deleuze, G. (2012). Derybos [Negotiations]. Vilnius: Baltos lankos.

[14] Deleuze, G. (1994). Difference and repetition. New York: Columbia university press.

[15] Deleuze, G., \& Guattari, F. (2004). A thousand plateaus: capitalism and schizophrenia. London: university of Minnesota press.

[16] Deleuze, G., \& Guattari, F. (2000). Anti - Oedipus. London: university of Minnesota press.

[17] Duoblienė, L. (2014). Learning as swimming: imaginational school project in Deleuzean way. Žmogus ir žodis, T. 16(4), 140-148.

[18] Duoblienè, L. (2017). Šizoidinė mokytoju situacija: pavojus tapatybei ir kūrybiškumo prielaida [The schizoid teacher situation: a danger for identity and a precondition for creativity]. Acta Paedagogica Vilnensia, 38, 11-24.

[19] Ellis, V. A. (2016). Introducing the creative learning principles: instructional tasks used to promote rhizomatic learning through creativity. The Clearing House: a Journal of Educational Strategies, Issues and Ideas, 89(4-5), 125-134, doi: 10.1080/00098655.2016.1170448.

[20] Europe Council Recommendations. (2018). Key competences for lifelong learning. Retrieved from https://eur-lex.europa.eu/legal content/LT/TXT/PDF/?uri=CELEX:32018H0604(01)\&fro $\mathrm{m}=\mathrm{EN}$ on 10.10 .2020 .

[21] Eurydice report .(2017). Key data on teaching languages at school in Europe.Retrieved January 11, 2020, from https://eacea.ec.europa.eu/national-policies/eurydice/content/key-data-teaching-languages-school-europe---2017-edition_en .

[22] Fendler, R. (2013). Becoming-learner. coordinates for mapping the space and subject of nomadic pedagogy. Qualitative Inquiry,19, 786-793. doi: 10.1177/1077800413503797

[23] Gabi J. (2013). Rhizomatic cartographies of belonging and identity within early years education. Ed. Dissertation. 1-326. Retrieved January 12, 2020, from https://espace.mmu. ac.uk/528248/1/Rhizomatic\%20cartographies\%20of\%20belonging\%20Josie\%20Gabi.pdf

[24] Geros mokyklos koncepcija [The conception of good school].(2015). Retrieved January 15, 2020, from https://www.smm.lt/uploads/documents/Pedagogams /Geros\%20mokyklos\%20koncepcija.pdf 
[25] Grant, M., \& Booth, A. (2009). A typology of reviews: an analysis of 14 review types and associated methodologies. Health Information and Libraries Journal, 26, 91-108.

[26] Koutropoulos, A., Bali, M., Honeychurch, S., Hamon, K., Hogue, R., Johnson, S., Leunissen, R. \& Singh, L. (2016). What is it like to learn and participate in Rhizomatic MOOCs? A collaborative autoethnography of \#RHIZO14. Current Issues in Emerging eLearning, 3, 41-59.

[27] Kristeva, J. (1969). Séméiôtiké: recherches pour une sémanalyse [Semiotics]. Paris: Edition du Seuil.

[28] Lian, A., Pineda,V. M. (2014). Rhizomatic learning: "As... when... and if..." a strategy for the ASEAN community in the 21st century. Beyond Words: A Journal on Language Education, Applied Linguistics and Curriculum \& Instruction, 2, 1-27.

[29] Mažeikis, G. (2013). Isikitinimai. Sąmoningumo metamorfozés [The persuasions. Metamorphoses of awareness]. Kaunas: Kitos knygos.

[30] Mackness, J., \& Bell, F. (2015). Rhizo14: A rhizomatic learning cMOOC in sunlight and in shade. Open Praxis, 7(1), 25-38.

[31] Mackness, J., Bell, F. \& Funes, M. (2016). The rhizome: a problematic metaphor for teaching and learning in a MOOC. Australian Journal of Educational Technology. 32(1), 78-91.

[32] Marshall, J. (2004). Poststructuralism, philosophy, pedagogy. Dordrecht \& Boston: Kluwer academic publishers.

[33] Masny, D. (2014). Disrupting ethnography through rhizoanalysis. Qualitative Research in Education, 3(3), 345-363.

[34] Peters, A., Burbules, M.C. (2003). Poststructuralism in educational research. Retrieved January 12, 2020, from: https://books.google.lt/books/about/Poststructuralism_and_Educational_ Resear.html?id=V9JIkfKadfgC\&source=kp_cover\&redir_esc $=y$

[35] Pocius, K. (2011). Geismas ir išlaisvinimas G. Deleuzo ir F. Guattari politinèje filosofijoje [Desire and liberation in political philosophy of G. Deleuze and F. Guattari]. Problemos, 79, 28-40.

[36] Rubavičius, V. (2010). Postmodernus kapitalizmas [Postmodern capitalism]. Kaunas: Kitos knygos.

[37] Sanford, K., Merkel, L., \& Madill, L. (2011). „There's no fixed course”: Rhizomatic learning communities in adolescent videogaming, The Journal of the Canadian Game Studies Association , $5(8), 50-70$.

[38] Semetsky, I. (2013). Learning with bodymind. In D. Masny (Ed.), Cartographies of becoming in education. Rotterdam: Sense Publishers.

[39] Semesky, I. (2007). Deleuze, education and becoming. Rotterdam: Sense publishers. Sage publication.

[40] St. Pierre E.,A. (2004). Deleuzian concepts for education: the subject undone, Educational Philosophy and Theory, 36(3), 283-296, doi: 10.1111/j.1469-5812.2004.00068.x

[41] Usher, R., Edwards, R. (1994). Postmodernism and education. New York: Columbia University Press.

[42] Žukauskaitè, A. (2011). Gilles'io Deleuze'o ir Felixo Guattari filosofija: daugialypumo logika [The philosophy of Gilles Deleuze and Felix Guattari: the logic of multiplicity]. Vilnius: Baltos lankos.

[43] Žukauskaitė, A. (2004). Geismo mašinos: psichoanalitinė ir šizoanalitinė perspektyva [Machines of desire: psychoanalitical and schizoanalitical perspectives]. Sociologija, 3, 27-32.

[44] Vidurinio ugdymo programos [Secondary school languages curriculum]. (2013). Retrieved January 15, 2020, from: https://www.smm.lt/uploads/documents/svietimas/ugdymo-programos/vidurinis-ugdymas/Kalbos_2_priedas.pdf.

[45] Waterhouse, M. (2011). Experiences of multiple literacies and peace: a rhizoanalysis of becoming. Ed. Dissertation. 1-351. Retrieved January 17, 2020, from https://ruor.uottawa.ca/ handle/10393/19942 